\title{
ANALYSIS OF LEARNING FACILITIES UTILIZATION IN ONLINE LEARNING IN CLASS IV STUDENTS IN SDN 021 NORTH SAMARINDA
}

\author{
Submitted: \\ 16 Desember 2021 \\ Accepted: \\ 30 Desember 2021 \\ Published: \\ 31 Januari 2022
}

\author{
Nurul Hikmah ${ }^{1}$, Afdal ${ }^{2}$, Junefra ${ }^{3}$. \\ nuruluwgm@gmail.com ${ }^{1}$, afdalpallaloi@yahoo.com ${ }^{2}$, \\ junefra07@gmail.com ${ }^{3}$ \\ PGSD, FKIP, UWGM Samarinda ${ }^{123}$ \\ *Corresponding Author
}

\begin{abstract}
This study aims to determine the use of learning facilities in online learning at SD Negeri 021 North Samarinda. The subjects of this study were school principals, fourth grade teachers and students. The method applied in this research is descriptive qualitative. The results of the study show that the utilization of learning facilities is still quite good, as can be seen from the interview rubric related to learning and online learning facilities. This is evidenced by interviews with the principal, teachers, and five interviewed students, showing that the differences in learning at this time still make it a little difficult for students to understand the lessons given so that the results in terms of student practice learning are still not optimal but learning in the form of student material still gets results which is maximum. Based on the description above, it can be concluded that the use of learning facilities in online learning for fourth grade students at SD Negeri 021 North Samarinda is going quite well.
\end{abstract}

Keywords: Utilization, learning facilities and learning online.

\section{INTRODUCTION}

Education is a teaching and learning process between teachers and students to gain knowledge and knowledge, experience and useful knowledge which is expected to be a provision for their future and the provision of their life journey. Education is a science that is required in schools through teaching and learning between teachers and students to provide intelligence, knowledge and good morals to students who will become the successors of this family, community, country and nation. Education is a conscious activity through formal education, non-formal and informal to derive one generation to the next through learning to increase the knowledge to someone who does not understand education.

Online Lerning still cannot be carried out properly due to various obstacles such as inadequate facilities, low economic conditions so that they cannot afford to buy quotas, geographical conditions that result in less stable internet networks, lack of 
community digital literacy which results in online learning not running optimally. (Sulastri, 2020).

The Big Indonesian Dictionary explains that facilities "means that it makes it easier to carry out tasks". Facilities associated with activities learning are facilities and infrastructure. Infrastructure is an indirect tool for examples such as the location, sports field, money, school buildings and others, facilities are direct tools, examples such as books, media lessons that teachers use, rooms and others that facilitate the learning process if a facility can maximize it good, then the learning outcomes to be achieved can be carried out well (Sunadi, 2010).

A good facilitator or able to understand a common goal will support activities to learning run successfully so that learning objectives can be achieved properly and optimally. Learning facilities are all facilities needed in learning activities, both moveable in order to support the success of educational goals that can run successfully.

Learning facilities are facilities and infrastructure that are needed in the teaching and learning process, without learning facilities the teaching and learning process will be an obstacle and cannot achieve maximum learning outcomes. Facilities, namely facilities and infrastructure that are very much needed for teaching and learning activities, especially during a pandemic like this, the facilities used and to support are not complete and what are most often needed are cell phones, quotas and internet networks where the three facilities are very helpful in the learning process during this pandemic. Whether or not a teaching and learning process runs smoothly is strongly influenced by whether or not the existing facilities are complete (Kartika, 2021).

Learning facilities are all the needs needed by students in launching the teaching and learning process, and supporting learning activities at school. In order to be more effective and efficient, students will be able to learn optimally and have satisfactory learning outcomes for students, teachers, schools and parents. If the learning facilities in a school are complete, the learning process will also run well and the presence of complete facilities will increase online learning supported by the learning facilities needed when online learning (Asih, 2017). 
Based on some of the definitions above, researchers can conclude that learning facilities are a necessity that schools need or infrastructure facilities that are needed by schools to support and expedite the online learning process and can improve so that the results are effective and efficient and students can learn optimally and can provide satisfactory improvement in learning.

Learning facilities are divided into two, namely facilities and infrastructure. Regarding the teaching and learning process, school infrastructure is moving indirectly, for example, sports equipment. While school facilities are moving directly to the teaching and learning process, examples as needed in learning during a pandemic like this are learning media used by teachers such as cell phones, quotas and internet networks (Nur, 2015). Learning facilities directly have a positive and significant effect on student achievement. Learning the online system or online directly has a positive and significant effect on student achievement. Amenities learn direct and significant positive effects on learning online systems or online (the Goddess,2021).

One of the challenges in carrying out online learning is that it requires adequate facilities and infrastucture, for example laptops, smartphones, computers, and internet networks (Handarini, 2020). Online learning is basically a distance learning process or online communication, which is known as online communication, network communication is communication system cush as computers, mobile phones and a device connected to the internet (Belawati, 2020).

The Teaching and learning process distance is a system that has existed since the mid 18th century. Since its inception, the teaching and learning process distance tenses applications in carrying out learning, ranging from the easiest and simplest applications to the slightly complicated ones.

Online learning, which is carried out remotely, is currently the goal of implementing online learning as a result of COVID-19. Online learning occurs when there is delivery of online information. The delivery of online information is known as the delivery of information in a network or online, delivery of information in a network or online or online learning request communication technology devices or systems such as mobile phones, laptops, computers or devices that can be connected or connected to the internet (Sutriyanti, 2020). 
Online learning was first recognized because of the influence of the development of electronic-based learning (e-learning) which was introduced by the University of Illinois through a computer-based learning system (Hardiiyanto). Online learning is a system that can facilitate students to learn more broadly, more, and varied. Through the facilities provided by the system, students can learn anytime and anywhere without being limited by distance, space and time. The learning materials that are studied are more varied, not only in verbal form, but also more varied such as visual, audio, and motion (Riyana, 2020).

Based on some of the definitions above, the researcher can conclude that online learning is a teaching and learning activity that is carried out remotely without being limited by time.

The benefits of learning online are that it can build communication, very efficient interactive discussions between teachers, students and parents. Both are the right means to make exams, questions and quizzes for students without time limits. The three teachers can easily provide material to students in the form of picture media and videos in learning besides that students can download these teaching materials and can be studied by students repeatedly (Pohan, 2020). The benefit of online learning is that it increases the level of one type of action or more that occurs by more than one person which has a learning effect between students and teachers with the learning process from anywhere and anytime that is not tied to time and place and makes it easier for students to learn the subject matter provided by the teacher, which is where online learning opens an easier space for students and teachers with such ease it can be expected to increase students in participating in online learning (Mustuti, 2020). Then the benefits of online learning are that it provides convenience for education in providing information transfer of subject matter in various situations and conditions (Herliandry, 2020).

Then the purpose of online learning is to launch student learning activities and to keep it going even during this pandemic by providing many interesting and easily accessible learning resources and a flexible and easy-to-understand learning process so as to avoid confusion among students, both in place and time. The implementation can be completely online, otherwise it can be combined with online learning and offline lessons or face to face directly but with an agreed agreement so that online learning 
can improve (Fahrina, 2020). Furthermore, the purpose of online learning is to continue to carry out the learning process during this pandemic which is not possible for the direct learning process which will result in the spread of the COVID-19 virus so that the learning process continues, the government takes a way, namely online learning and also so that teachers can make design or design learning that is unique and as good as possible so that it can improve online learning by utilizing the use of technology as creatively as possible (Hairun, 2020). The purpose of learning online is something that the teacher cannot determine whether the learning objectives online to be achieved from the learning outcomes are achieved or not because online learning is based on the understanding of each student in responding to the lessons given by the teacher and many obstacles that cause learning to take place between other limitations quotas owned by students, children's readiness when learning time has started, and the disruption of the internet network is good or not and so on (Kusumah, 2020).

In this study, researchers used two variables: learning and online learning facilities. Given the first variable, researchers found that study in the facilities studied many types of learning facilities, so researchers are focusing on whatsapp and the internet. Researchers found several uses of facilities that are still functioning in online learning today, for example, textbooks on the theme of tics and school buildings. The researcher also found some problems in the learning process chiefly in the fourth grade in the learning process using only one application, namely whatsapp application and an inadequate internet network so that students who follow the learning process or when sending assignments must find an adequate internet network so that they can send assignments or follow in the learning process, there are even students who have to join friends or even don't follow the learning process because they only have one cellphone and their parents often use it for work.

Based on the explanation above, researchers are interested in researching and knowing about the analysis of learning facilities utilization in online learning in class IV students in SDN 021 Nort Samarinda. The purpose of this study was to explain and determine the use of learning facilities utilization in online learning in class IV students in SDN 021 North Samarinda. 


\section{METHOD}

\section{Types of Research}

This research used a descriptive qualitative approach, qualitative research method is a study that intends to understand the phenomena experienced by the subject, research for example behavior, perception, motivation, action, etc., holistically and by means of description in the form of words and language in a special natural context and by applying various natural methods. In educational studies, qualitative research can seal their right to understand various phenomena attitudes of educators, students, teachers and in the process pembelajaran (Sugiyono 2016).

\section{Place and Time of}

Research This study aims to obtain an overview, clear, complete, and easy information for researchers to carry out research. So, the researcher determined that the research location was at SDN 021 North Samarinda. This research has been carried out for two months.

\section{Research Subject The}

The subject of this research is the principal of SDN 021 North Samarinda as well as teachers who act as the use of learning facilities during online learning and students who take part in online learning.

\section{Data Collection Techniques Data}

Data collection techniques used in this study were interviews and documentation. The researcher conducted a data validity test by means of triangulation of sources. The results of checking the validity of the data in this study, is to re-check the source of the data obtained as comparison material (Sugiyono 2016).

\section{Data Analysis Techniques}

Data analysis techniques in the therapy, right there are three stages of data reduction that sharpens the form of analysis, directing, classifying, discarding unnecessary and organizing data in a manner such that until the final conclusion can be drawn and verified. This process continues as long as the research is running because it 
becomes an inseparable part of data analysis. Furthermore, the presentation of data, data analysis activities cannot be avoided, making it possible for researchers to develop themes or categories, so that researchers can know for sure what steps to take next. Then drawing conclusions, from this stage the findings from the research are reinforced with proven meanings.

\section{RESULTS}

The results of this study are data or information obtained from research results that are in accordance with events that are in the field or according to what is in the field. The results of this study are to find out the data that has been obtained in the form of interviews and documentation based on the focus of research in this study, the researchers describe the results of the data obtained relating to the use of learning facilities in online learning.

1. Learning Facilities

\section{a. Learning Facility Process}

1) Principal Interview

Based on the results of an interview with Mr. ZAI as the principal at SD Negeri 021 North Samarinda on Monday, April 26, 2021, at 10.00 WITA until the end of the process in the online learning facility the teacher provides subject matter in the form of text messages and photos through class groups via the whatsapp application and the internet with a schedule that has been determined by the teacher and when collecting assignments in the form of videos, students usually send their video assignments to their class groups, while assignments in the form of material are collected at school with a schedule for collecting assignments that have been arranged by the teacher, informing them in the form of text messages via the whatsapp application and the are obstacles when using the whatsapp application and internet application, namely in the form of an internet network which is a little difficult to access the internet network and the cellphones owned by students are also limited so it requires students to alternate with each other and his parents as well as his brother and sister 
when using it. Where the school is located a bit far from the city so that accessing the internet network is a bit constrained by sthis situation, students must first find a good internet network or rent wifi to be able to use the whatsapp application.

Sometimes with such circumstances, the school implements learning as offline well by the way the teacher informs via text messages using the whatsapp application and students come to school at the time determined by the teacher to take material in the form of a theme book and a sheet of guide paper for students to learn which In a sheet of guide paper, a period of time is usually given for one week and when taking the material the teacher explains a little of the material given so that students understand the material given and the task given is in the form of student material collecting it at school and lending each package book. theme for each student with a loan period determined by the teacher.

2) Teacher Interview

Based on the results of an interview with Ms. YS as a homeroom teacher for grade IV at SD Negeri 021 North Samarinda on Monday, April 26, 2021 at 09.40 WITA until it was finished that the learning facility process in the form of whatsapp application and internet in the learning process the teacher provided materials or assignments that given via whatsapp and the internet in class groups and sometimes there are obstacles such as the students long time to respond when learning begins because the cell phones taking owned by students are the cellphones of their parents so they have to take turns with their parents to work and not all students have a place to access a good internet network so this makes students hampered when participating in learning and when collecting assignments the teacher must first collect then the students collect their assignments.

3) Student Interviews

Based on the results of interviews with MI class IV at SD Negeri 021 North Samarinda on Monday, April 26, 2021, at 09.13 WITA until finished, the process of learning facilities online in the form of whatsapp application in the process students prepare equipment such as cell phones, books, pens 
and networks internet is good but there are obstacles when the teacher gives material and assignments, sometimes these students do not understand.

Based on an interview with SR on Monday 26 April 2021, at 09.27 WITA, that during this pandemic, parents are required to be able to adapt to the current situation. It is also related to the results of the FN interview on Monday 26 April 2021, at 08.52 WITA, Ardelia Putri on Monday. April 26, 2021, at 09.05 WITA, SL on Monday April 26, at 09.19 WITA until it is finished that in the process of learning facilities in the online form of whatsapp application and internet in the process when the teacher has given material in class groups via whatsapp students must first prepare their cell phones, good internet network, books and pens. However, there are perceived obstacles, namely in the form of a difficult internet network and having to find an internet network first when participating in the learning process and cell phones limited that must take turns with parents, brothers and sisters when using and sometimes delivering material in the form of text messages makes students less comfortable. understand so that it hinders the learning process a little online.

Based on the results of the interviews with principals, teachers and students above, it can be concluded that principals, teachers and students can overcome the learning facility in online learning process that is running during the COVID-19 pandemic in the form of whatsapp application and internet at this time, although it is a bit constrained cell phones by the limited number of that students have and internet network that is difficult to access but students still try to understand the material given.

b. Preparation in the Use of Study Facilities

1) Principal Interview

Based on the results of an interview with Mr. ZA as the principal at SD Negeri 021 North Samarinda on Monday, April 26, 2021, at 10.00 WITA until it is finished that preparations are being made for now to overcome the internet network which slightly constrained, therefore the school installed wifi to make it easier for students and local teachers to access the internet 
network, but there are obstacles for now only one application is still being used, namely the whatsapp application because to use other applications that can be more adequate it cannot be implemented because some cell phones students are still inadequate.

2) Teacher Interview

Based on the results of an interview with Ms. YS as a homeroom teacher for grade IV at SD Negeri 021 North Samarinda on Monday, April 26, 2021 at 09.40 WITA until it was finished that the main preparations prepared were in the form of whatsapp application, quotas, subject matter, good internet, why use the whatsapp application because the only application that can be used at SD Negeri 021 North Samarinda for online learning is currently being implemented due to inadequate conditions such as internet which is a little difficult to access so the whatsapp application that can be used for now is internet quota which is very much needed for the learning system during the covid-19 pandemic without learning quote online, it is complicated to run, besides that the sales place is a little far away and must anticipate beforehand so that learning can run smoothly and the third is the internet which is currently to access the internet in SD Negeri 021 North Samarinda is a bit constrained, only certain places have easy access to the internet, so it is necessary to find a good internet so that online learning can run well, then prepare materials and assignments when starting online learning.

3) Student Interview

Based on the results of the interview with MI class IV on Monday, April 26 2021, at 09.13 WITA until it was finished that the preparations were only cell phones, notebooks, and pens because everything else was available such as the internet because this student had wifi at his home. alone.

Based on the results of interviews with SR class IV on Monday April 26 2021, at 09.27 WITA until finished, it is also related to the results of interviews with FN class IV on Monday April 26 2021, at 08:52 WITA, AP class IV on Monday April 26 2021, at 09.05 WITA and SL class IV at SD Negeri 021 North Samarinda on Monday, April 26, at 09.19 WITA that the 
preparations made are to provide notebooks, pens, cell phones, good internet networks, quotas and money to rent wifi because accessing the internet at SD Negeri 021 North Samarinda is a bit constrained.

Based on the results of the interviews with principals, teachers and students above, it can be concluded that principals, teachers and students can cope with preparations for using learning facilities that are ongoing during the COVID-19 pandemic in the form of whatsapp application and internet at this time, although it is a little constrained cell phones by the limited number of that students have and the internet network is a little difficult to access.

c. Obstacles in Learning Facilities

1) Principal Interview

Based on the results of an interview with Mr. ZA as the principal at SD Negeri 021 North Samarinda on Monday, April 26, 2021, at 10.00 WITA until it was finished, the obstacles that have occurred since the implementation of online learning in the Covid-19 era are in SD Negeri 021 North Samarinda, namely cell phones the lack of that make some students have to take turns with their parents, brother or sister when using them and the internet network which is slightly constrained when accessing the internet and the provision of material in the form of text messages from the teacher sometimes makes students not understand. The constraint of the internet network makes the school as soon as possible to install wifi in the school in order for students to take part in online learning.

2) Teacher Interview

Based on the results of an interview with Mrs. YS as a homeroom teacher for grade IV at SD Negeri 021 North Samarinda on Monday, April 26, 2021 at 09.40 WITA until it was finished, the obstacles that occurred since the implementation of online learning during the COVID-19 pandemic at SD Negeri 021 North Samarinda, which is still using one type of application, namely the whatsapp application only because the internet network is a little difficult to access which is used in the online learning process. 
Sometimes students and parents who accompany their children to study do not understand or do not understand directly with the material given by the teacher in the form of text messages given by the teacher, unlike face-toface which can be given a broad explanation of the material and it is possible for students to ask questions directly. if something is not understood, so to overcome the problem the teacher there usually gives an explanation in the form of a video or students and their parents can meet directly with the teacher to explain what is not understood.

3) Student Interviews

Based on the results of interviews with MI class IV on Monday, April 26, 2021, at 09.13 WITA until completion, the obstacles experienced since online learning was implemented were that sometimes they did not understand or did not understand the material in the form of text messages given via whatsapp or assignments. given by the teacher.

Based on the results of interviews with SR class IV on Monday April 26 2021, at 09.27 WITA, it is also related to the results of interviews with FN class IV on Monday April 26 2021, at 08:52 WITA, AP class IV on Monday April 26 2021, at 09.05 WITA and fourth grade SL at SDN 021 North Samarinda on Monday, April 26, at 09.19 WITA that the obstacles experienced since learning was online implemented, namely when starting online learning these students must first find a good internet network and their own mobile phone less so that they have to take turns with their brother or sister or their parents when using cell phones and internet networks which are slightly constrained when accessing the internet and sometimes students do not understand the material or assignments given by the teacher via whatsapp during online learning .

Based on the results of interviews with principals, teachers and students above, it can be concluded that principals, teachers and students can overcome the obstacles that occur by providing wifi in schools in order to make it easier for students to access the network for online learning. Today's is certainly different from learning before online laerning applied so that it still makes students and parents who accompany their children to learn not 
understand the material or assignments given but students still try to understand the material and assignments given.

d. Results From UtilizingLearning Facilities

1) School Principal Interview

Based on the results of an interview with Mr. ZA as the principal at SD Negeri 021 North Samarinda on Monday, April 26, 2021, at 10.00 WITA until the end, the results that can be seen since the implementation of online learning are still quite good from the results of online learning there are good results and some are not good, for example in SD Negeri 021 North Samarinda from the online learning process in terms of student practice there achieve poor results while in terms of material the results achieved are very satisfying and the school continues to try help and facilitate students so that in online learning they can achieve the online learning outcomes maximum possible.

2) Teacher Interview

Based on the results of an interview with Ms. YS as a homeroom teacher for grade IV at SD Negeri 021 North Samarinda on Monday, April 26, 2021 at 09.40 WITA until the end, the results that can be seen since the implementation of online learning are still quite good due to differences in the process current learning with learning before the covid-19 pandemic is very different so it needs even more maximum adaptation for students because what the teacher conveys in the form of learning material is still not necessarily for students to understand what is being conveyed so that the results achieved are a bit constrained but there are other aspects of learning. The results that are still achieved are mastery of the material where students can still provide satisfactory results.

3) Student Interviews

Based on the results of interviews with SR class IV on Monday, April 26, 2021, at 09.27 WITA, it is also related to the results of interviews with FN class IV on Monday, April 26, 2021, at 08.52 WITA, Muhammad Ismail class IV on Monday, December April 26, 2021, at 09.13 WITA, AP class IV 
on Monday April 26 2021, at 09.05 WITA and SL class IV at SD Negeri 021 North Samarinda on Monday April 26, at 09.19 WITA.

That the results achieved are still quite good because of the difference in the different learning processes before face-to-face learning is replaced with online learning at this time which makes student learning outcomes decrease in practical learning where practical learning must be explained face-to-face so that students can be clear when given an explanation because currently online learning requires an explanation of assignments or materials in the form of online so it makes students a little difficult to understand lessons in the form of practice but on the other hand lessons in the form of student materials can still provide maximum results.

Based on the results of the interviews with principals, teachers and students above, it can be concluded that the principal, teachers and students that the results obtained from the use of learning facilities are still quite good because the differences in learning at this time still make it a little difficult for students to understand the lessons given. In terms of practical learning, students there are still not optimal, but learning in the form of student material there still gets maximum results.

2. Online Learning

a. Media and Methods used in Online Learning

1) Principal Interview

Based on the results of an interview with Mr. ZA as the principal at SD Negeri 021 North Samarinda on Monday, April 26, 2021, at 10.00 WITA until it was finished that the media and methods used in SD Negeri 021 North Samarinda since online learning is implemented is the first of the media. The media used in the form of mobile phones is assisted by using the whatsapp application, for now whatsapp application only the can be used because it is constrained by the internet network which is a little difficult to access, so the method used for now is online learning and sometimes offline learning such as students coming to school with a time and schedule determined by the teacher and take the material and material guide with a working time limit that has been determined by the teacher and the blend of 
material that has been prepared by the teacher so that students just see the guide and work on the material provided by the teacher.

2) Teacher Interview

Based on the results of an interview with Ms. YS as a homeroom teacher for grade IV at SD Negeri 021 North Samarinda on Monday, April 26, 2021 at 09.40 WITA until it was finished that the media and methods used since online learning was implemented are currently there are two types of media the first one uses online media, namely mobile phones assisted by the whatsapp application and the second media, offline namely theme books which are distributed one by one to students and material guides so that students can be directed in the learning process and the methods used for online learning and sometimes offline learning such as students coming to school with the time and schedule determined by the teacher and taking material and material guides with a time limit for working on the material that has been determined by the teacher and material guides that have been prepared by the teacher so that students just see the guide and work on the material provided by the teacher and provide material that is not too difficult so that it is easy for students to work because the learning process is not directly or face to face in class, sometimes the teacher gives material in the form of interesting videos so that students can understand the material given by the teacher and do not give a lot of assignments to students so that students do not experience boredom and to keep the spirit in learning when online learning. However, there are several obstacles, namely the internet network which is a bit difficult to access, the cell phones owned by students are inadequate, and some students still need more adaptation to the current learning process.

3) Student Interviews

Based on the results of interviews with SR class IV on Monday, April 26, 2021, at 09.27 WITA, it is also related to the results of interviews with FN class IV on Monday April 26 2021, at 08:52 WITA, MI class IV on Monday, the 26th April 2021, at 09.13 WITA, Ardelia Putri for fourth grade 
on Monday, 26 April 2021, at 09.05 WITA, and fourth grade SL at SD Negeri 021 North Samarinda on Monday, 26 April, at 09.19 WITA.

The media and methods used today are in the form of mobile phones assisted by the whatsapp application, while learning media are offline in the form of open lesson themes, notebooks and pens, while the methods used are online learning and sometimes offline learning.

Based on the results of the interviews with principals, teachers and students above, it can be concluded that principals, teachers and students use mobile phones assisted by the whatsapp application for online learning media while learning theme books, notebooks and pens are offline media while the method used is online learning and sometimes offline learning.

\section{DISCUSSION}

Online learning which is carried out at SD Negeri 021 North Samarinda remotely which is currently the goal of implementing online learning as a result of COVID-19. Submission of information in online learning requires devices or communication technology systems to support the learning process such as mobile phones, laptops, computers or devices that can be connected or connected to the internet. This is in accordance with the theory expressed by (Sutriyanti, 2020).

The process of online learning facilities that are running during the covid-19 pandemic at SDN 021 North Samarinda in the form of whatsapp application and internet at this time although slightly constrained cell phones by the limited owned by students and internet networks that are difficult to access, students still try to understand the material provided in online learning. Learning facilities which are facilities and infrastructure that are needed for the teaching and learning process, there are no learning facilities for the learning and teaching process will be an obstacle and cannot achieve maximum learning outcomes. pandemic times like this. This is in accordance with the theory expressed by (Zulkifil, 2020).

Schools can overcome the problems of learning facilities that usually occur by providing wifi in schools so that it can make it easier for students to access the network. Online lerning today is certainly different from before online learning applied 
so that it still makes students and parents who accompany their children learn not understand the material or assignments given but students still learning try to understand the material and assignments given. This is in accordance with the theory expressed by (Asih, 2017).

Research conducted by researchers proves that the use of learning facilities is still quite good. This is evidenced by interviews with principals, teachers, and students that the differences in learning at this time still make it a little difficult for students to understand the lessons given so the results in terms of student practice learning are still not optimal but learning in the form of student materials still gets maximum results with facilities learning for online learning using mobile phones assisted by the whatsapp application for media in offline using learning theme books, notebooks and pens.

This is in accordance with research conducted by (Yuliani, 2019) with the title "Utilization of Media in Based Learning Processes Online- in the Pandemic Period of SD Negeri 5 Bengkulu City ". That the results of the study indicate that teachers and students in utilizing online media use whatsapp grub to carry out learning discussions, whatsapp photos and whatsapp videos to carry out school assignments, whatsapp documents to carry out exams. Online learning by applying whatsapp is considered effective because the teaching and learning process continues well, the learning materials that the teacher wants to provide can be absorbed by students, and the results received in the online teaching and learning process are also good, seen from the increasing student report cards.

This is in accordance with research conducted by (Hariyadi \& Hariyanti, 2020) with the title "The Importance of Information Technology-Based Learning Facilities on Student Learning Outcomes". The results of the study show tha the existing IT-based learnng facilities in schools affect student learning outcomes. To further improve the quality of learning,teachers and students must use school facilities optimally so that the desired taget is achieved and student learning outcomes show good changes. 


\section{CONCLUSION}

Based on the results of the discussion on the use of learning facilities in online learning for fourth grade students at SD Negeri 021 North Samarinda that: 1) The process of learning facilities, that the principal, teachers and students can overcome the learning facility process although a little constrained by cell phones owned by some students are limited, inadequate and the internet network is a little difficult to access; 2) Preparation in the use of learning facilities, that principals, teachers and students can overcome preparations in the use of learning facilities even though it is a bit constrained cell phones by the limited number of owned by some students, inadequate and the internet network is a little difficult to access; 3) Obstacles in learning facilities, that principals, teachers and students can overcome the obstacles that occur even though the cell phones owned by some students are limited, inadequate and the internet network is a little difficult to access; 4) The results from the use of learning facilities, that the principal, teachers and students achieved quite good results, although they were a bit constrained by the differences in current learning and the cell phones owned by some students were limited, inadequate and the internet network was a little difficult to access; 5) The media and methods applied in online learning, that the media and methods used by school principals, teachers and students are quite good although it is a little constrained cell phones that they owned by some students are limited, inadequate and the internet network is a little difficult to access. Based on the description above, it can be concluded that the results of using learning facilities in online learnng for fourth grade students at SD Negeri 021 North Samarinda are going quite well.

\section{REFERENCES}

Agung, L. (2018). Char Asih, DAS (2017). The effect of using learning facilities in the natural environment on science process skills.Formative: Scientific Journal of MathematicsNatural Sciences Educationand,7(1).

Belawati, T. (2020). Online Learning Books. Open University Ministry of Education and Culture South Tangerang-15437, Banten-Indonesia.

Dewi, ER (2021). The Influence of Competencies and Learning Facilities on Online Learning and Achievement of Middle School Students in Makassar City During 
the Covid 19 Pandemic.Indonesian Journal of Learning Education and Counseling,3(2), 194-205.

Fahrina, A., Amelia, K., \& Zahara, CR (Eds.). (2020).Minda Guru Indonesia: Innovative Teachers and Learning During the COVID-19 Pandemic. Syiah Kuala University Press.

Hairun, Y. (2020).Evaluation and assessment in learning. Depublish.

Handarini, OI, \& Wulandari, SS (2020). Online learning as a study from home (SFH) effort during the COVID-19 pandemic.Journal of Office Administration Education (JPAP),8(3), 496-503.

Hariyadi, AB, \& Hariyati, N. The Importance of Information Technology-Based Learning Facilities on Student Learning Outcomes.

Herliandry, LD, Nurhasanah, N., Suban, ME, \& Kuswanto, H. (2020). Lessons learned during the COVID-19 pandemic.JTP-Journal of Educational Technology,22(1), 65-70.

Kartika Putri Sari, K. (2021).THE EFFECT OF ONLINE MEDIA USE IN THE TIME OF COVID-19 ON THE LEARNING COMMUNICATION PROCESS AMONG STUDENTS OF UIN SUSKA RIAU(Doctoral dissertation, Sultan Syarif Kasim State Islamic University, Riau).

Kusumah, W. (2020). Creating Effective Learning Patterns from Home.

Latifah, U. (2018). THE EFFECT OF LEARNING FACILITIES ON STUDENTS' MOTIVATION AND LEARNING OUTCOMES IN MIN 5 TULUNGAGUNG.

Mastuti, R., Maulana, S., Iqbal, M., Faried, AI, Arpan, A., Hasibuan, AFH, ... \& Vinolina, NS (2020).Teaching from home: From independent learning to independent learning. Our Writing Foundation.

Nur, S. (2016).Correlation of Completeness of Learning Facilities on Learning Outcomes of Civics at Sma 2 Polewali.Pepatudzu: Social Education and Social Media,10(1), 47-67.

Pohan, AE (2020).The concept of online learning based on a scientific approach. CV Publisher. Sarnu Lucky.

Riyana, C., \& Pd, M. (2020). Online learning concept.On-Line Learning Module,1.

Sugiyono, S. (2013). Qualitative Quantitative Research Methods and R\&D. Alphabet. 
Sutriyanti, NK (Ed.). (2020).Sowing the Seeds of the Dharma from a Multidisciplinary Perspective. Ahmar Scholar Foundation of Indonesia.acter Education Integration in Social Studies Learning. Historia: Jurnal Pendidik dan Peneliti Sejarah, 12(2), 392.

Sulastri, D., Maula, LH, \& Uswatun, DA (2020). Utilization of Digital Platforms in Online Learning During the Covid-19 Pandemic Period in Elementary Schools.Journal of Basic Education,11(02), 219-229.

Sunadi, L. (2013). The effect of learning motivation and the use of learning facilities on student achievement in economics class XI IPS at SMA Muhammadiyah 2 Surabaya. Journal of Economic Education (JUPE),1(3).

Yuliani, F. (2021). THE UTILIZATION OF MEDIA IN THE ONLINE-BASED LEARNING PROCESS IN THE PANDEMIC TIME OF SD NEGERI 5 CITY OF BENGKULU. Journal of Bachelor of Communication Studies,2(1), 1-11. 